\title{
Isolation and Characterization of the Outer and Cytoplasmic Membranes of Pseudomonas cepacia
}

\author{
By HOSMIN ANWAR, MICHAEL R. W. BROWN, * ROBERT M. COZENS \\ AND PETER A. LAMBERT \\ Microbiology Research Group, Department of Pharmacy, University of Aston in Birmingham, \\ Birmingham B4 7ET, U.K.
}

(Received 24 June 1982)

\begin{abstract}
A method is described for the separation of the outer membrane (OM) from the cytoplasmic membrane (CM) of Pseudomonas cepacia grown in nutrient broth and in chemically defined media under different nutrient depletions. The method is particularly valuable since it is effective when applied to stationary phase cells. Enzyme activities indicated that the contamination of the $\mathrm{OM}$ with the $\mathrm{CM}$ was less than $5 \%$. The OM protein profile of magnesiumdepleted cells was much simpler than that of the iron-depleted and nutrient broth grown cells. The apparent molecular weights of the OM proteins of magnesium-depleted cells were: 40000 , 36000,24500 and 14500 . Iron depletion induced the synthesis of an OM protein with apparent molecular weight of 66000 . The OM proteins with apparent molecular weights of 40000,36000 and 24500 were heat-modifiable and the 24500 dalton protein was found also to be affected by the presence of 2 -mercaptoethanol. The OM consisted of $50 \%$ protein and $20 \%$ phospholipid and the rest was probably LPS while the CM consisted of $80 \%$ phospholipid and $20 \%$ protein. The major phospholipid in both membranes was phosphatidylethanolamine with a smaller amount of phosphatidylglycerol and a trace amount of phosphatidylcholine; the OM contained more phosphatidylethanolamine than the CM.
\end{abstract}

\section{INTRODUCTION}

The cell envelope of Gram-negative bacteria is known to include two membranes, the outer membrane (OM) and cytoplasmic membrane (CM). The separation of these two membranes was first successfully achieved in Escherichia coli by Miura \& Mizushima (1968) by a technique involving isopycnic sucrose density gradient centrifugation. Modification of the technique was made by Osborn et al. (1972) for Salmonella typhimurium and separation has also been achieved in Pseudomonas aeruginosa (Mizuno \& Kageyama, 1978) and Proteus mirabilis (Hasin et al., 1975).

Pseudomonas cepacia, usually known as a plant pathogen, has little or no pathogenic activity against healthy individuals. In persons with poor antimicrobial resistance, however, it can play the part of an 'opportunist' pathogen, causing severe and potentially fatal sepsis (Phillips \& Eykyn, 1971; Speller et al., 1971). It was also reported that $P$. cepacia could survive in an inorganic salt solution which contained commercial $0.05 \%$ benzalkonium chloride for 14 years (Geftic et al., 1979). Nutrient depletion affects the composition of bacteria (Boggis et al., 1979; Ellwood \& Tempest, 1972; Holme, 1972) and also plays an important role in resistance to drugs (Brown \& Melling, 1969a, b; Brown, 1975; 1977; Kenward et al., 1978, 1979) and body defences (Finch \& Brown, 1978; Costerton et al., 1979; Gilbert \& Brown, 1980; Griffiths et al., 1980).

Abbreviations: CM, cytoplasmic membrane; OM, outer membrane; DPG, diphosphatidylglycerol; PC, phosphatidylcholine; PE, phosphatidylethanolamine; PG, phosphatidylglycerol; PL, phospholipid. 
There have been no reports of the preparation and analysis of the OM of $P$. cepacia. This paper describes a method for the separation of the $\mathrm{OM}$ from the $\mathrm{CM}$ and their chemical analysis using $P$. cepacia grown under different types of nutrient depletion. Since the method is effective when applied to stationary phase cells (Cozens \& Brown, 1981), where most other techniques have been found to give unsatisfactory results, it could be of general value.

\section{METHODS}

Bacteria and culture conditions. The organism used throughout this study was Pseudomonas cepacia NCTC 10661. The cells were grown in nutrient broth or in chemically defined medium (glucose, $20 \mathrm{~mm} ; \mathrm{KCl}, 3 \mathrm{~mm} ; \mathrm{NaCl}$, $3 \mathrm{~mm} ;\left(\mathrm{NH}_{4}\right)_{2} \mathrm{SO}_{4}, 12 \mathrm{~mm} ; \mathrm{MgSO}_{4} .7 \mathrm{H}_{2} \mathrm{O}, 3.2 \mathrm{mM} ; \mathrm{K}_{2} \mathrm{HPO}_{4}, 1.2 \mathrm{mM} ; \mathrm{FeSO}_{4} .7 \mathrm{H}_{2} \mathrm{O}, 0.02 \mathrm{mM} ; \mathrm{MOPS}, 50 \mathrm{mM}$; $\mathrm{pH}$ 7.4). For magnesium depletion the concentration of $\mathrm{Mg}^{2+}$ was decreased to $0.019 \mathrm{mM}$ and for iron depletion $\mathrm{Fe}^{2+}$ was decreased to $0.040 \mu \mathrm{M}$. The components of the medium, except glucose, were mixed in $4 \times 51$ conical flasks and autoclaved at $121^{\circ} \mathrm{C}$ for $30 \mathrm{~min}$. At the time of inoculation, sterile glucose solution (autoclaved at $121^{\circ} \mathrm{C}$ for $10 \mathrm{~min}$ ) was added and the final volume of each culture was 21 .

An overnight culture in Fe-depleted chemically defined medium was used as an inoculum. The cells were harvested at $8000 \mathrm{~g}$ for $10 \mathrm{~min}$, washed once with sterile normal saline and resuspended in this solution to give an $A_{470}$ of about $2 \cdot 0$. This bacterial suspension $(3.0 \mathrm{ml})$ was used to inoculate the medium (2l) described above. Cultures were incubated at $37 \pm 1{ }^{\circ} \mathrm{C}$ for $24 \mathrm{~h}$ using magnetic stirrers to achieve vigorous aeration. The maximum $A_{470}$ reached by $\mathrm{Mg}$-depleted cells was approx. 1.2 and was 0.8 for Fe-depleted cells, while the $A_{470}$ reached by $\mathrm{O}_{2}$ depleted nutrient broth was $\mathbf{3 \cdot 2}$.

Glassware. Glassware was washed in Extran $300(\mathrm{BDH})$ rinsed once in distilled water, once in $1 \%(\mathrm{v} / \mathrm{v}) \mathrm{HCl}$, and finally rinsed thoroughly in double distilled water.

Preparation of the cell envelopes for the separation of the outer and cytoplasmic membranes. The method was described by Hancock \& Carey (1979) with some modifications (Cozens \& Brown, 1981). Eight litres of culture were harvested by centrifugation at $8000 \mathrm{~g}$ for $10 \mathrm{~min}$. This and all subsequent operations were done at $4{ }^{\circ} \mathrm{C}$. The cells were washed once with $30 \mathrm{mM}$-Tris/ $\mathrm{HCl}$ buffer, $\mathrm{pH} 8.0$ and resuspended in $20 \mathrm{ml} 20 \%$ (w/v) sucrose in $30 \mathrm{mM}$ Tris/ $\mathrm{HCl}$ buffer, $\mathrm{pH} 8.0$ containing $2 \mathrm{mg}$ DNAase and $2 \mathrm{mg}$ RNAase (Sigma). The cells were passed three times through the French pressure cell at $1055 \mathrm{~kg} \mathrm{~cm}^{-2}, 4 \mathrm{mg}$ egg-white lysozyme was added and the mixture was placed in the ice-bath for $30 \mathrm{~min}$. The preparation was diluted with $40 \mathrm{ml} 30 \mathrm{mM}$-Tris/ $\mathrm{HCl}$ buffer, $\mathrm{pH} 8 \cdot 0$. Unbroken cells were removed by centrifugation at $1500 \mathrm{~g}$ for $10 \mathrm{~min}$, usually it was necessary to repeat this procedure once. The supernatant was centrifuged at $38000 \mathrm{~g}$ for $60 \mathrm{~min}$. The pellet was resuspended in $20 \mathrm{ml} 20 \%$ sucrose in $30 \mathrm{mM}$ Tris/ $\mathrm{HCl}$ buffer, $\mathrm{pH} 8.0$. A sample $(2 \mathrm{ml})$ was layered on to a two-step sucrose gradient containing $9 \mathrm{ml}$ each of $70 \%$ and $60 \%(\mathrm{w} / \mathrm{v})$ sucrose in $30 \mathrm{mM}$-Tris/ $\mathrm{HCl}$ buffer, $\mathrm{pH} 8.0$. The gradient was centrifuged at $100000 \mathrm{~g}$ in an MSE $20^{\circ}$ angle rotor for 14 to $17 \mathrm{~h}$. Three bands were observed, designated upper, lower and intermediate bands. Each was removed by suction from the top with a syringe and diluted with cold distilled water, centrifuged at $38000 \mathrm{~g}$ for $60 \mathrm{~min}$ and washed twice with distilled water to remove traces of sucrose. The resultant pellets were resuspended in a small amount of distilled water and kept at $-20^{\circ} \mathrm{C}$.

Total protein assay. The protein content of the $\mathrm{OM}$ and $\mathrm{CM}$ was estimated by the Lowry method using bovine serum albumin as the standard.

Enzyme assay of the outer and cytoplasmic membranes. The enzymes were assayed according to the procedures described by Mizuno \& Kageyama (1978). Succinate dehydrogenase, D-lactate dehydrogenase, gluconate dehydrogenase and glucose dehydrogenase were determined by incubating mixtures containing $60 \mathrm{~mm}$-phosphate buffer (pH 7.2), $10 \mathrm{mM}-\mathrm{KCN}, 10 \mu \mathrm{g}$ phenazine methosulphate, $20 \mu \mathrm{g}$ dichlorophenol indophenol, $25 \mathrm{mM}$-sodium succinate (or $2.5 \mathrm{mM}$-D-lactate, or $20 \mathrm{~mm}$-gluconate, or $30 \mathrm{mM}$-glucose) and the membrane fraction (50 to $100 \mu \mathrm{g}$ protein) in a volume of $1 \mathrm{ml}$. The rate of decrease in absorbance at $600 \mathrm{~nm}$ was recorded for more than $10 \mathrm{~min}$ at room temperature. NADH oxidase was determined by incubating mixtures containing $50 \mathrm{~mm}$ - Tris/ $\mathrm{HCl}(\mathrm{pH} \mathrm{8.0)}$, $0.12 \mathrm{mM}-\mathrm{NADH}, 0.2 \mathrm{mM}$-DTT and the membrane fraction (50 to $100 \mu \mathrm{g}$ protein) in a volume of $1 \mathrm{ml}$. The rate of decrease in absorbance at $340 \mathrm{~nm}$ was recorded at room temperature for more than $10 \mathrm{~min}$.

Lipid extraction from the outer and cytoplasmic membranes. The readily extractable lipids were extracted by the method of Ames (1968). These were dissolved in $1 \mathrm{ml}$ methanol/chloroform $(2: 1)$ and $20 \mathrm{ml}$ acetone at $-10^{\circ} \mathrm{C}$ was added to precipitate the phospholipids (PL). After storage overnight at $-10^{\circ} \mathrm{C}$, PL were removed by centrifugation in a tared centrifuge tube and dried over $\mathrm{P}_{2} \mathrm{O}_{5}$ in vacuo to constant weight.

Assay of phospholipids. Ascending TLC was used to fractionate the PL into individual components. Solvent I [chloroform/methanol/water $(65: 25: 4)$ ] (Ames, 1968) was used. After development, the plates were air-dried and sprayed with phosphate spray reagent (Ames, 1968). The ratio of individual PL, identified by co-chromatography with standards, was determined by densitometry with a Chromoscan 200/201 microdensitometer (Joyce Loebl \& Co. Ltd, Gateshead, Northumberland, U.K). The area under each peak was estimated by weighing and the ratio of PE :PG was calculated (see results). No extra spots were observed after charring the plates at $160^{\circ} \mathrm{C}$ for $2 \mathrm{~h}$. 
SDS-PAGE. The method was described by Lugtenberg et al. (1975) using $15 \%(\mathrm{w} / \mathrm{v})$ acrylamide. The samples were denatured at $100^{\circ} \mathrm{C}$ for $5 \mathrm{~min}$ with or without 2 -mercaptoethanol or at $60^{\circ} \mathrm{C}$ for 30 min with 2mercaptoethanol. Electrophoresis was carried out at room temperature with a constant current of $40 \mathrm{~mA}$ per gel. Gels were stained for proteins overnight in a solution of $0 \cdot 1 \%$ Brilliant Blue R (Sigma) in $50 \%$ methanol-10\% acetic acid, and destained in 5\% methanol-10\% acetic acid.

\section{RESULTS}

Separation of the outer and cytoplasmic membranes

Sucrose density gradient centrifugation of crude membranes of $P$. cepacia yielded three bands of material designated upper, intermediate and lower bands. CM marker enzymes (Osborn $e t$ al., 1972) were detected in significantly higher activity in the upper bands than in the lower bands (Table 1). Succinate dehydrogenase was present in abundance in the upper bands under all nutritional conditions, whereas the others were only detected in the upper bands of $\mathrm{Mg}$ depleted cells. As previously reported by Manniello et al. (1979) 2-keto-3-deoxyoctonic acid (KDO) could not be detected in either whole cells or any of the membrane fractions and could not be used as an OM marker. The results indicated that, in common with other Gram-negative bacteria, the upper band contained CM and the lower band contained OM material.

\section{The outer membrane protein patterns of $P$. cepacia}

Analysis of the proteins by SDS-PAGE showed that the proteins of the CM (slots A and D) and the OM (slots C, F and G) were significantly different (see Fig. 1). There were only slight differences between the intermediate fraction (slots $\mathrm{B}$ and $\mathrm{E}$ ) and the OM fraction (slots $\mathrm{C}$ and F), but to reduce cross contamination of the OM with CM or vice versa, the intermediate fraction was always separated from the upper and lower bands and discarded. In Fig. 1, the OM protein profile of $\mathrm{Mg}$-depleted cells (slot $\mathrm{F}$ ) was much simpler than that of Fe-depleted and nutrient broth grown cells (slots $\mathrm{G}$ and $\mathrm{C}$, respectively). Several proteins found in the $\mathrm{OM}$ of $\mathrm{Fe}-$ depleted and nutrient broth grown cells were absent from $\mathrm{Mg}$-depleted cells. The apparent molecular weights of the OM proteins of Mg-depleted cells were: $40000,36000,24500$ and 14500. The OM protein with an apparent molecular weight of 36000 was present in a large quantity in cells grown under all conditions and might correspond to the pore-forming proteins (porins) observed in other organisms to be in the range of 33000 to 40000 (Nikaido \& Nakae, 1979). The synthesis of the OM protein with an apparent molecular weight of 66000 was induced with Fe-depleted $P$. cepacia and appeared as a major band but was absent from cells grown under other nutritional conditions (Fig. 1, slot G). Two other major OM proteins with apparent molecular weights of 17000 and 18500 were found only with grown cells (Fig. 1, slot C).

\section{Table 1. Localization of the activity of several enzymes in the outer membrane and cytoplasmic membrane of P. cepacia NCTC 10661}

The values for the CM and OM were obtained from the upper and lower bands, respectively, of the sucrose gradient.

\begin{tabular}{|c|c|c|c|c|c|c|}
\hline \multirow[b]{3}{*}{ Enzyme } & \multicolumn{6}{|c|}{ Specific activity* } \\
\hline & \multicolumn{2}{|c|}{ CDM Mg - } & \multicolumn{2}{|c|}{$\begin{array}{l}\text { Medium } \dagger: \\
\text { CDM Fe- }\end{array}$} & \multicolumn{2}{|c|}{ NB } \\
\hline & OM & $\mathbf{C M}$ & OM & $\mathbf{C M}$ & OM & $\mathrm{CM}$ \\
\hline Succinate dehydrogenase & $19 \cdot 2$ & 315 & $11 \cdot 4$ & 187 & $9 \cdot 5$ & 218 \\
\hline D-Lactate dehydrogenase & ND & 82 & ND & ND & - & - \\
\hline Gluconate dehydrogenase & ND & 21 & ND & ND & - & - \\
\hline NADH oxidase & ND & 34 & - & - & - & - \\
\hline
\end{tabular}

ND, Not detectable.

* Specific activity is expressed as nmol substrate converted $\min ^{-1}$ (mg protein) ${ }^{-1}$.

$+\mathrm{NB}$, nutrient broth; CDM Mg - , chemically defined medium, magnesium depleted; $\mathrm{CDM} \mathrm{Fe}-$, chemically defined medium, iron depleted. 


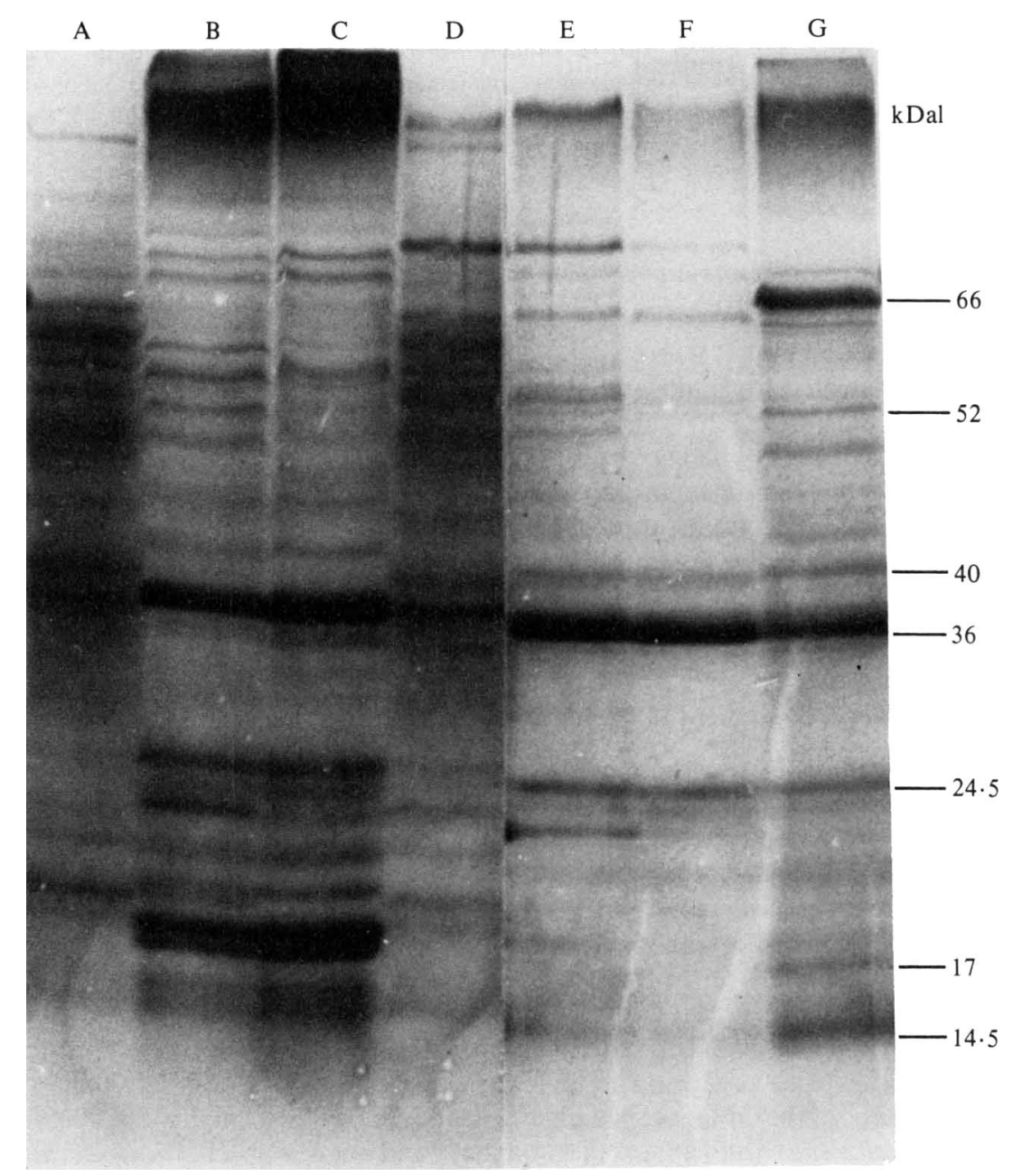

Fig. 1. SDS-PAGE of the OM and CM of $P$. cepacia NCTC 10661. Slots: A, the upper band (CM), B, the intermediate band and $C$, the lower band $(\mathrm{OM})$ of nutrient broth grown cells; $D$, the upper band $(\mathrm{CM}), \mathrm{E}$, the intermediate and $\mathrm{F}$, the lower band $(\mathrm{OM})$ of $\mathrm{Mg}$-depleted cells and $\mathrm{G}$, the lower band $(\mathrm{OM})$ of Fe-depleted cells.

\section{Effect of solubilization temperature and 2-mercaptoethanol on the electrophoretic mobilities of the} outer membrane proteins of $P$. cepacia

In the presence of 2-mercaptoethanol $(0 \cdot 15 \% \mathrm{v} / \mathrm{v})$, one OM protein moved with an apparent molecular weight of 24500 (Fig. 2, slots A, D, G). However, when 2-mercaptoethanol was excluded from the denaturing buffer, it moved with an apparent molecular weight of 22500 in all three growth conditions used (Fig. 2, slots B, E, H).

Several major OM proteins of $P$. cepacia were found to be heat-modifiable. These proteins had apparent molecular weights of 40000,36000 and 24500 when they were denatured at $100^{\circ} \mathrm{C}$ for $5 \mathrm{~min}$ in the presence of 2-mercaptoethanol (Fig. 2, slots A, D, G). However, they moved as diffuse bands with apparent molecular weights greater than 70000 when they were solubilized at $60^{\circ} \mathrm{C}$ for $30 \mathrm{~min}$ (Fig. 2, slots C, F, I). The OM protein with an apparent molecular weight of 66000 , induced when iron was growth limiting was not modified by either heat or 2mercaptoethanol (Fig. 2, slots D, E, F). 


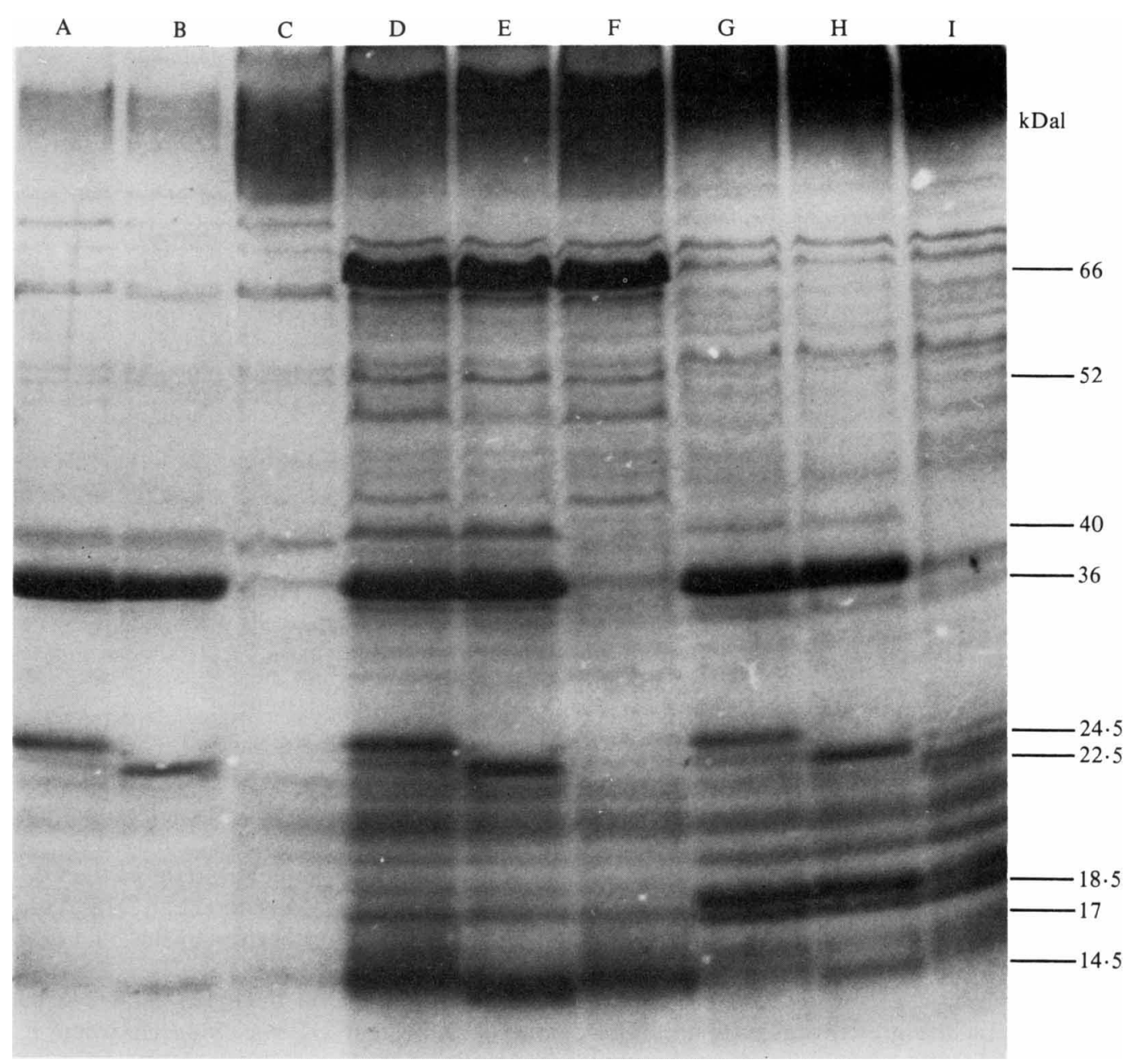

Fig. 2. The effects of heating and 2-mercaptoethanol on the electrophoretic mobilities of the OM proteins of $\boldsymbol{P}$. cepacia grown under different nutrient limitations. Slot $\mathbf{A}, \mathbf{M g}$-depleted cells (denatured at $100{ }^{\circ} \mathrm{C}$ for 5 min with $5 \%$-mercaptoethanol, condition I); B, Mg-depleted cells (denatured at $100^{\circ} \mathrm{C}$ for $5 \mathrm{~min}$ without 2-mercaptoethanol, condition II); C, Mg-depleted cells (denatured at $60^{\circ} \mathrm{C}$ for $30 \mathrm{~min}$ with 5\% 2-mercaptoethanol, condition III); D, Fe-depleted cells (condition I); E, Fe-depleted cells (condition II); F, Fe-depleted cells (condition III); G, nutrient broth grown cells (condition I); H, nutrient broth grown cells (condition II); I, nutrient broth grown cells (condition III).

Protein and phospholipid contents of the outer membrane and cytoplasmic membrane of $P$. cepacia

The results are shown in Table 2 . In all cases, the $\mathrm{OM}$ was found to be relatively rich in protein while the CM was rich in PL. The OM was found to consist of about $50 \%$ protein and $20 \% \mathrm{PL}$ (presumably the rest was LPS) while the CM was found to consist of $80 \% \mathrm{PL}$ and $20 \%$ protein. PL detected in the study were mainly phosphatidylethanolamine (PE) and phosphatidylglycerol (PG). Traces of phosphatidylcholine (PC) were also detected. Diphosphatidylglycerol (DPG) was not detected even after charring at $160^{\circ} \mathrm{C}$ for $2 \mathrm{~h}$. The $\mathrm{OM}$ contained a slightly higher $P E: P G$ ratio than the $C M$ under all growth conditions studied. A similar enrichment of $P E$ in the OM of $E$. coli has been reported by Lugtenberg \& Peters (1976). The PE : PG ratio in the OM and $C M$ varied considerably with the growth conditions, being highest in the Fe-depleted cells and lowest in Mg-depleted cells. 
Table 2. Protein and lipid composition of the outer membrane and cytoplasmic membrane of $P$. cepacia NCTC 10661 grown under different types of nutrient depletion

Data are means of two duplicate determinations. Abbreviations: REL, readily extractable lipid; FAN, free fatty acid and neutral lipid (calculated from REL-PL); PL, phospholipid; PE, phosphatidylethanolamine; PG, phosphatidylglycerol.

\begin{tabular}{|c|c|c|c|c|c|c|c|}
\hline \multirow[b]{2}{*}{ Medium* } & \multirow{2}{*}{$\begin{array}{l}\text { Membrane } \\
\text { fraction }\end{array}$} & \multicolumn{3}{|c|}{ Percentage of dry wt } & \multicolumn{3}{|c|}{ Percentage of total PL } \\
\hline & & Protein & REL & FAN & PL & PE & PG \\
\hline \multirow[t]{2}{*}{ NB } & OM & $50 \cdot 7$ & $20 \cdot 8$ & 2 & $18 \cdot 8$ & 87 & 13 \\
\hline & $\mathbf{C M}$ & 14.9 & $79 \cdot 9$ & 12 & 67.9 & 82 & 18 \\
\hline \multirow[t]{2}{*}{$\mathrm{CDM} \mathrm{Fe-}$} & OM & $44 \cdot 5$ & $26 \cdot 3$ & $2 \cdot 6$ & $23 \cdot 7$ & 93 & 7 \\
\hline & $\mathbf{C M}$ & 12.9 & $85 \cdot 4$ & $7 \cdot 1$ & $78 \cdot 3$ & 88 & 12 \\
\hline \multirow[t]{2}{*}{ CDM Mg - } & OM & $51 \cdot 2$ & $19 \cdot 8$ & $2 \cdot 6$ & $17 \cdot 2$ & 73 & 27 \\
\hline & $\mathrm{CM}$ & 15.9 & $76 \cdot 6$ & 7.9 & $68 \cdot 7$ & 54 & 46 \\
\hline
\end{tabular}

* See Table 1 for definitions.

\section{DISCUSSION}

The methods for separating the OM and CM described by Miura \& Mizushima (1968) and Osborn et al. (1972) are applicable only to exponential phase cells. The method described in this paper is suitable for both stationary phase cells and for slow-growing cells obtained from the chemostat. The method was also found to be successful for $P$. aeruginosa PAO1, $P$. aeruginosa NCTC 6750 and $E$. coli $\mathrm{K} 12$ in this laboratory.

Amongst the CM marker enzymes assayed (Osborn et al., 1972) only succinate dehydrogenase could be reliably detected under all nutritional conditions. Its activity in the OM fractions was less than $5 \%$ of that found in the CM, which is acceptable for many purposes. KDO was not detected in whole cells or in any of the membrane fractions confirming published data that the LPS of $P$. cepacia does not contain KDO (Manniello et al., 1979).

The success of the separation was also verified by analysing the protein patterns of the OM and CM in SDS-PAGE. Fig. 1 shows that the protein profiles of the CM (slots A and D) and the OM (slots $C$ and $F$ ) were significantly different. In common with other organisms, the $O M$ contains large amounts of relatively few major protein species.

The synthesis of several OM proteins of Gram-negative bacteria has been shown to be affected by the growth environment. The synthesis of protein D1 was induced when $P$. aeruginosa was grown in the presence of glucose (Hancock \& Carey, 1980). Iron limitation induced the synthesis of several OM proteins with apparent molecular weights in the range of 60000 to 85000 in P. aeruginosa (Mizuno \& Kageyama, 1978) which might be involved in the translocation of iron across the OM (Meyer et al., 1979). Magnesium limitation induced the synthesis of protein H1 in P. aeruginosa (Nicas \& Hancock, 1980) and was suggested to be involved in resistance to aminoglycosides (Hancock et al., 1981) and also to polymyxin (Nicas \& Hancock, 1980). Protein e of E. coli K12 (Overbeeke \& Lugtenberg, 1980) and protein P of $P$. aeruginosa (Hancock et al., 1982) were induced when the cells were grown under phosphate limitation. In this study, it was found that the OM protein profile of $\mathrm{Mg}$-depleted cells (Fig. 1, slot F) was much simpler than that of Fe-depleted cells and nutrient broth grown cells (Fig. 1, slots $\mathrm{G}$ and $\mathrm{C}$, respectively). The synthesis of the $\mathrm{OM}$ protein with an apparent molecular weight of 66000 was induced when $P$. cepacia was grown under iron depletion. It appeared as a major band in this condition (Fig. 1, slot G). The synthesis of two OM proteins with apparent molecular weights of 17000 and 18500 was induced when $P$. cepacia was grown in nutrient broth. The function of these two OM proteins is still unclear.

The electrophoretic mobilities of several major OM proteins of $P$. aeruginosa have been shown to be affected by the solubilization temperature and the concentration of 2-mercaptoethanol (Hancock \& Carey, 1979). At low concentration of 2-mercaptoethanol (0-0.01\%), protein F moved with an apparent molecular weight of 33000 . However, at higher concentrations of 2mercaptoethanol $(0 \cdot 1-0.5 \%)$, it moved with an apparent molecular weight of 42000 (its $\mathrm{F}^{*}$ form). Protein $\mathrm{F}$ was also found to be heat-modifiable. At low temperature (below $88^{\circ} \mathrm{C}$ ), it 
moved with an apparent molecular weight of 39000 . However, at high temperature, it moved with an apparent molecular weight of 41000 . In this study, the electrophoretic mobility of one OM protein of $P$. cepacia was found to be affected by the presence of 2 -mercaptoethanol and the electrophoretic mobilities of several OM proteins were affected by the solubilization temperature (Fig. 2). In the presence of 2-mercaptoethanol, one protein moved with an apparent molecular weight of 24500 . However, when 2-mercaptoethanol was omitted from the denaturing buffer, it moved with an apparent molecular weight of 22500 in all three growth conditions used. The electrophoretic mobility of another major OM protein with an apparent molecular weight of 36000 was not affected by the presence of 2-mercaptoethanol. This 36000 dalton protein therefore behaves differently from the protein $F$ of $P$. aeruginosa. The results presumably indicate that this protein either does not contain disulphide bonds or that they are protected from reduction by 2 -mercaptoethanol.

Several major OM proteins of $P$. cepacia were found to be heat-modifiable (Fig. 2). These proteins had apparent molecular weights of 40000,36000 and 24500 when they were solubilized at $100{ }^{\circ} \mathrm{C}$ for $5 \mathrm{~min}$. However, they moved as a single diffuse band with an apparent molecular weight greater than 70000 when they were solubilized at $60^{\circ} \mathrm{C}$ for $30 \mathrm{~min}$.

The effects of solubilization temperature on the electrophoretic mobilities of the heatmodifiable proteins of $P$. cepacia appeared to be different from those reported for $P$. aeruginosa (Hancock \& Carey, 1979) and E. coli (Reithmeier \& Bragg, 1977). In P. aeruginosa and E. coli, the proteins moved slower (higher molecular weights) when they were denatured at high temperature and moved faster (lower molecular weights) when they were denatured at low temperature. Such behaviour might be explained in terms of there being two different stable conformational states for each protein in SDS solution. This is the case in E. coli (Nakamura \& Mizushima, 1976; Reithmeier \& Bragg, 1977). However, the heat-modifiable proteins of $P$. cepacia moved slower when they were denatured at low temperature and moved faster when they were denatured at high temperature, the opposite to that observed in $P$. aeruginosa and $E$. coli. The effect might be explained in terms of the existence of two different stable conformational states of the protein molecule in SDS solution as proposed for P. aeruginosa and E. coli; alternatively the proteins might exist as dimers or trimers in nature and when they are denatured at high temperature they are split into monomers, therefore they move faster in the SDSpolyacrylamide gel when denatured at higher temperatures.

On a dry weight basis, the OM was found to consist of approximately $50 \%$ protein, $20 \% \mathrm{PL}$ and the rest was probably LPS while the CM was found to consist of $80 \% \mathrm{PL}$ and $20 \%$ protein. The relatively low content of protein in the CM might be due to the release of the protein from the $\mathrm{CM}$ during the breakage of the cells, as high activities of $\mathrm{CM}$ marker enzymes such as succinate dehydrogenase were detected in the supernatant after centrifugation of the whole envelope in the preparation of the membranes (data not shown). These enzymes were presumably loosely bound to the CM and released when the cells were broken by passage through the French pressure cell.

PL detected in the OM and CM were mainly PE and PG with trace amounts of PC. DPG was not detected in the study, even after charring at $160^{\circ} \mathrm{C}$ for $2 \mathrm{~h}$. Pseudomonas BAL-31 was also reported to lack DPG (Diedrich \& Cota-Robles, 1974). The PE :PG ratio was higher in the OM than in the CM in all three growth conditions used in the study. Enrichment of the OM in PE has also been observed in Pseudomonas BAL-31 (Diedrich \& Cota-Robles, 1974), P. mirabilis (Rottem et al., 1975), S. typhimurium (Osborn et al., 1972) and E. coli K12 (Lugtenberg \& Peters, 1976).

The protein and PL contents of the OM and CM of different nutrient-depleted cells were found to vary only slightly (Table 2). However, a marked variation in the PE:PG ratio was observed among nutrient-depleted cells. The ratio was found to be highest in Fe-depleted cells and lowest in $\mathrm{Mg}$-depleted cells.

In conclusion, we have shown that the protein and PL composition of the OM of P. cepacia varies with the nutritional conditions under which the cells were grown. Experience with other Gram-negative organisms shows that such variation is likely to have a profound effect on the sensitivity of the cells to antimicrobial agents and body defences. 


\section{REFERENCES}

AMES, G. F. (1968). Lipids of Salmonella typhimurium and Escherichia coli: Structure and metabolism. Journal of Bacteriology 95, 833-843.

Boggis, W., KenWARD, M. A. \& Brown, M. R. W. (1979). Effects of divalent cations in the growth medium upon sensitivity of batch-grown Pseudomonas aeruginosa to EDTA and polymyxin. Journal of Applied Bacteriology 47, 477-488.

BRown, M. R. W. (1975). The role of the cell envelope in resistance. In Resistance of Pseudomonas aeruginosa, chapter 3. Edited by M. R. W. Brown. London: John Wiley.

BRowN, M. R. W. (1977). Nutrient depletion and antibiotic susceptibility. Journal of Antimicrobial Chemotherapy 3, 198-201.

Brown, M. R. W. \& Melling, J. (1969a). Loss of sensitivity to EDTA by Pseudomonas aeruginosa grown under conditions of magnesium limitation. Journal of General Microbiology 54, 439-444.

BRown, M. R. W. \& Melling, J. (1969b). Role of divalent cations in the action of polymyxin $B$ and EDTA on Pseudomonas aeruginosa. Journal of General Microbiology 59, 263-274.

Burdon, D. W. \& WhitBy, J. L. (1967). Contamination of hospital disinfectant with Pseudomonas species. British Medical Journal 2, 153-155.

Costerton, J. W., Brown, M. R. W. \& Sturgess, J. M. (1979). The cell envelope: its role in infection. In Pseudomonas aeruginosa: Clinical Manifestations of Infection and Current Therapy, pp. 41-62. Edited by R. G. Doggett. London: Academic Press.

Cozens, R. M. \& BRown, M. R. W. (1981). Separation of outer and cytoplasmic membranes from stationary phase and chemostat cultures of Pseudomonas aeruginosa. Society for General Microbiology Quarterly 8, 131.

Diedrich, D. L. \& Cota-Robles, E. H. (1974). Heterogenicity in lipid composition of the outer membrane and cytoplasmic membrane of Pseudomonas BAL-31. Journal of Bacteriology 119, 10061018.

Ellwood, D. C. \& TEMPEST, D. W. (1972). Effects of environment on bacterial wall content and composition. Advances in Microbial Physiology 7, 83-117.

FINCH, J. E. \& BROWN, M. R. W. (1978). The effect of growth environment on the killing of Pseudomonas aeruginosa by rabbit polymorphonuclear leukocytes and by cationic proteins. Infection and Immunity $\mathbf{2 0 ,}$ 340-346.

Geftic, S. G., HeymanN, H. \& Adair, F. W. (1979). Fourteen year survival of Pseudomonas cepacia in a salts solution preserved with benzalkonium chloride. Applied and Environmental Microbiology 37, 505-510.

GilberT, P. \& Brown, M. R. W. (1980). Cell wallmediated changes in sensitivity of Bacillus megaterium to chlorhexidine and 2-phenoxy-ethanol, associated with growth rate and nutrient limitation. Journal of Applied Bacteriology 48, 223-230.

Griffiths, E., Rogers, H. J. \& Bullen, J. J. (1980). Iron, plasmids and infection. Nature, London 284, 508-509.

Hancock, R. E. W. \& Carey, A. M. (1979). Outer membrane of Pseudomonas aeruginosa: heat and 2mercaptoethanol modifiable proteins. Journal of Bacteriology 140, 902-910.
Hancock, R. E. W. \& Carey, A. M. (1980). Protein D1 - a glucose inducible, pore-forming protein from the outer membrane of Pseudomonas aeruginosa. FEMS Microbiology Letters 8, 105-109.

HaNCOCK, R. E. W., Raffle, V. J. \& Nicas, T. I. (1981). Involvement of the outer membrane in gentamicin and streptomycin uptake and killing in Pseudomonas aeruginosa. Antimicrobial Agents and Chemotherapy 19, 777-785.

Hancock, R. E. W., Poole, K. \& Benz, R. (1982). Outer membrane protein $\mathrm{P}$ of Pseudomonas aerugin$o s a$ : regulation by phosphate deficiency and formation of small anion-specific channels in lipid bilayer membranes. Journal of Bacteriology 150, 730-738.

Hasin, M., RotTEM, S. \& RAzIN, S. (1975). The outer membrane of Proteus mirabilis. I. Isolation and characterization of the outer and cytoplasmic membrane fractions. Biochimica et biophysica acta 375, 381-394.

HOLME, T. (1972). Influence of environment on the content and composition of bacterial envelopes. Journal of Applied Chemistry and Biotechnology 22, 391-399.

Kenward, M. A., Brown, M. R. W., Hesslewood, S. R. \& Dillon, C. (1978). Influence of R-plasmid RP1 of Pseudomonas aeruginosa on cell wall composition, drug resistance and sensitivity to cold shock. Antimicrobial Agents and Chemotherapy 13, 447-453.

KenWard, M. A., Brown, M. R. W. \& Fryer, J. J. (1979). The influence of calcium or manganese on the resistance to EDTA, polymyxin B or cold shock and the composition of Pseudomonas aeruginosa grown in glucose- or magnesium-depleted batch cultures. Journal of Applied Bacteriology 47, 489-503.

Lugtenberg, E. J. J. \& Peters, R. (1976). Distribution of lipids in cytoplasmic and outer membranes of Escherichia coli. Biochimica et biophysica acta 441, 3847.

Lugtenberg, B., Meijers, J., Peters, R., van Der HOECH, P. \& VAN ALPHEN, L. (1975). Electrophoretic resolution of the 'major outer membrane protein' of Escherichia coli K-12 into four bands. FEBS Letters 58, 254-258.

Manniello, J. M., Heymann, H. \& Adair, F. W. (1979). Isolation of atypical lipopolysaccharides from purified cell walls of Pseudomonas cepacia. Journal of General Microbiology 112, 397-400.

Meyer, J. M., MoCk, M. \& Abdallah, M. A. (1979). Effect of iron on the protein composition of the outer membrane of fluorescent Pseudomonads. FEMS Microbiology Letters 5, 395-398.

MiURA, T. \& Mizushima, S. (1968). Separation by density gradient centrifugation of two types of membranes from spheroplast membrane of Escherichia coli K-12. Biochimica et biophysica acta 150, 159-161.

Mizuno, T. \& Kageyama, M. (1978). Separation and characterization of the outer membrane of Pseudomonas aeruginosa. Journal of Biochemistry 84, 179191.

NaKamura, K. \& Mizushima, S. (1976). Effects of heating in dodecyl sulphate solution on the conformational and electrophoretic mobility of isolated major outer membrane proteins from Escherichia coli K-12. Journal of Biochemistry 80, 1411-1422. 
Nicas, T. I. \& Hancock, R. E. W. (1980). Outer membrane protein $\mathrm{Hl}$ of Pseudomonas aeruginosa: involvement in adaptive and mutational resistance to EDTA, polymyxin B and gentamicin. Journal of Bacteriology 143, 872-878.

NIKAIDO, H. \& NAKAE, T. (1979). The outer membrane of gram-negative bacteria. Advances in Microbial Physiology 20, 163-250.

Osborn, M. J., Gander, J. E. \& Parisi, E. (1972). Mechanism of assembly of the outer membrane of Salmonella typhimurium. Isolation and characterization of the cytoplasmic and outer membranes. Journal of Biological Chemistry 247, 3962-3972.

OVERBEEKE, N. \& LUGTENBERG, B. (1980). Expression of outer membrane protein e of Escherichia coli K-12 by phosphate limitation. FEBS Letters 112, 229-232.
PhIllips, I. \& EyKYN, S. (1971). Pseudomonas cepacia (multivorans) septicemia in an intensive care unit. Lancet 1, 375-377.

Reithmeier, R. A. F. \& Bragg, P. D. (1977). Molecular characterization of a heat-modifiable protein from the outer membrane of Escherichia coli. Archives of Biochemistry and Biophysics 178, 527-537.

RotTem, S., Hasin, M. \& RazIN, S. (1975). The outer membrane of Proteus mirabilis. II. The extractable lipid fraction and electron paramagnetic resonance analysis of the outer and cytoplasmic membranes. Biochimica et biophysica acta 375, 395-405.

SPElleR, D. C., StePhen, M. E. \& Viant, A. C. (1971). Hospital infection by Pseudomonas cepacia. Lancet 1, 798-799. 